\title{
Establishment of pregnancy and its immunological implications in the pig
}

\author{
E. Koch \\ AFRC Institute of Animal Physiology, Babraham, Cambridge CB2 4AT, U.K.
}

\begin{abstract}
Summary. The consideration of the fetus as a semi-allograft by virtue of its paternally inherited histocompatibility antigens is generally accepted. Many hypotheses have been put forward to explain the immunological acceptance of the conceptus by the maternal immune system, but no single theory has proved to be adequate. Most studies so far have been carried out with laboratory rodents and men but corresponding investigations of farm animals and especially the pig are limited. Because striking differences exist between various species, e.g. with respect to the type of placentation, litter size, gestation time and hormone production, the relevance of studies in rodents and men for other species has to be established. This review examines, in the context of available information from other mammalian systems, whether the pig conceptus expresses and presents antigens to the maternal immune system, to what extent the sow recognizes and responds to these antigens, and, in the event of recognition, the mechanisms by which the conceptus avoids and exploits the consequences of histoincompatibility.
\end{abstract}

\section{Introduction}

One of the most remarkable properties of the immune system is its ability to recognize certain components as 'self and to discriminate them from "non-self' structures against which an immune response needs to be mounted. The consequence of this ability is impressively demonstrated by the fact that skin grafted from one individual of an outbred species to another is usually rejected within 10-14 days. Although this example represents an experimental condition, the immune system is confronted with a very similar problem in the course of mammalian reproduction. Starting with the deposition of the ejaculate within the female genital tract during copulation, the maternal organism is in contact with foreign tissues throughout the whole of the gestation period. However, since viviparity has proved to be an effective form of reproduction and rarely results in the immunological rejection of the conceptus, some form of protection must have been developed during the evolu. tion of this mode of reproduction. Many hypotheses have been advanced to explain the survival of the fetus in utero, but no single proposal has been found adequate to cover all aspects involved in the immunoprotection of the fetal allograft.

So far, most studies have been carried out in laboratory rodents and man, while corresponding investigations in farm animals, and especially in the pig, are rather limited. Since striking differences exist between various species in their type of placentation, litter size, gestation period and hormone production, the relevance of studies in rodents and man to other species remains to be established. This paper examines the immunological implications of pregnancy in the pig in the context of results available from different mammalian systems.

\section{Cellular and molecular basis of the allo-immune response}

Cells of all higher vertebrates possess genetically coded antigens on their surface which can provoke 
an immune response after transfer into other individuals of the same (allograft) or alien species (xenograft). The antigens involved in graft rejection are known as transplantation or histocompatibility antigens. While in the mouse as many as 30 different genetic loci involved in chronic rejection of grafts (minor histocompatibility antigens) have been described, in all species studied so far one system of linked genes has been found to be predominant and associated with an acute rejection of allogeneic tissues and tumour grafts. The sum of these genes is referred to as the major histocompatibility complex ( $\mathrm{MHC}$ ). Extensive studies of the $\mathrm{MHC}$ have been carried out in mouse (H-2) and man (HLA), but from comparative studies in many mammalian species it is obvious that striking similarities exist between the MHCs of different species not only in their organization, but also in their functional and biochemical properties (Sachs, 1983).

The MHC in the pig is the swine lymphocyte antigen (SLA) complex (Vaiman, Renard, LeFage, Ameteau \& Nizza, 1970; Viza, Sugar \& Binns, 1970). Like the MHC antigens in other species, those of the pig can be divided into Class I (SLA-A, B, C) and Class II (SLA-D) antigens. Class I antigens consist of a heavy glycoprotein chain of molecular weight about 45000 and $\beta_{2}$-microglobulin, the structural gene for which does not belong to the MHC. Studies on Class II antigens suggest that at least 2 loci are involved which code for a two-chain structure consisting of components with molecular weights of about 26000 and 32000 (Chardon, Vaiman, Renard \& Arnoux, 1978; Lunney \& Sachs, 1978, 1979; Vaiman, Chardon \& Renard, 1979; Chardon, Renard \& Vaiman, 1981; Pennington, Lunney \& Sachs, 1981; Osborne, Lunney, Pennington, Sachs \& Rudikoff, 1983).

Class I antigens are expressed on almost all cells of the body, while Class II antigens appear mainly on B-lymphocytes and some macrophages. As the $\mathrm{MHC}$ is extraordinarily polymorphic and the alleles are expressed co-dominantly, all individuals in an outbred population can be considered as unique with regard to the combination of these antigens.

The biological function of the MHC antigens is now well established. They serve as a means for the discrimination between 'self and 'non-self', and they control cellular interactions in the immune responses (Matzinger \& Zamoyska, 1982). It has been shown that all sub-populations of T-lymphocytes, the effector cells of the cellular immune response, are MHC restricted in the sense that they recognize foreign antigens only in connection with their own MHC molecules. While cytotoxic T-cells $\left(T_{c}\right)$ and some suppressor $T$-cells $\left(T_{s}\right)$ utilize Class 1 MHC molecules for this purpose, helper $T$-cells $\left(T_{h}\right)$ and delayed-type hypersensitivity $T$-cells $\left(T_{d h}\right)$ recognize extrinsic antigen only in the context of self Class II MHC molecules. However, there is one exception to this rule. In the case of $\mathrm{MHC}$ alloantigens themselves, T-cells do not react in a MHC restricted manner, and it has been suggested that both classes of allogeneic $\mathrm{MHC}$ molecules may resemble self $\mathrm{MHC}$ plus foreign antigen (Simpson, 1984).

From in-vitro studies it became generally accepted that cytotoxic $T$-cells represent the predominant effector cells in allograft rejection. Following this view, precursors of helper T-cells respond to Class II alloantigens on lymphocytes and accessory cells (macrophages, reticulum cells), and then proliferate in the presence of interleukin 1 (IL-1), a lymphokine released by macrophages and certain other cell types. With the help provided by interleukin 2 (1L-2), a lymphokine of helper T-cell origin, precursors of cytotoxic T-cells, bearing receptors for Class I MHC alloantigens, eventually proliferate and differentiate into effector cells able to lyse target cells (see Simpson, 1984). Studies of adult mice that have been thymectomized, irradiated and bone marrow reconstituted have led to a different hypothesis. It has been shown that T-cells, phenotypically identical (L.yt $1^{+}$) to those mediating a delayed-type hypersensitivity (DTH) reaction, could alone restore an allograft response. It is thought that these cells, once stimulated, release lymphokines which react with macrophages, mast cells and probably other cells to cause the destruction of an allograft (Loveland $\&$ McKenzie, 1982). The significance of cytotoxic T-cells in the defence against viruses and other intracellular infections in vivo is well established (Simpson, 1984).

Although antibodies do not usually provoke a graft rejection, it has been shown that a humoral response can provoke a hyperacute kidney rejection. Antibody involvement has also been observed during rejection of lymphoid tissue in the mouse, and is found in chronic rejection processes 
(Carpenter, D'Apice \& Abbas, 1976). Since the immune system represents a multiple interconnected and complex regulated network whose function is based on the co-operation of T- and B-cells, a humoral response will inevitably influence the cellular response and vice versa. Immunoglobulins are produced by plasma cells which differentiate from B-lymphocytes. B-cells usually require two signals: the binding of antigen to the receptor (surface-bound immunoglobulin of the same specificity as the subsequently secreted antibody), and the assistance of helper T-cells (see Howard, 1985). Suppressor T-cells on the other hand, can down-regulate the immune response. The mechanism of suppressor $\mathrm{T}$-cell action is still far from clear but it has been shown that they can suppress several immune reactions, e.g. DTH, antibody production, cytotoxic T-cell function and lymphokine production, in an antigen-specific as well as a non-specific manner (Simpson, 1984).

\section{Antigen expression and presentation by seminal components and tissues of the conceptus}

As a consequence of mating and intrauterine development spermatozoa, seminal plasma and the tissues of the conceptus represent possible sources of antigenic material for the sensitization of the female immune system.

Spermatozoa carry a number of different antigens including sperm-specific autoantigens, histocompatibility antigens and blood group antigens (see Hogarth, 1982), but it is not clear whether spermatozoa actively express all of these antigens or whether some are simply absorbed from seminal plasma (Erickson, Lewis \& Butley, 1981). Lymphocyte antigens have been shown to be present in small amounts on boar spermatozoa and, from inhibition tests, it seems improbable that all of these antigens originate from the seminal plasma (Jilek \& Veselský, 1972).

Seminal plasma constitutes a complex mixture of secretions from different sources in the male genital tract and contains a number of components with autoantigenic as well as alloantigenic properties (see Hogarth, 1982). With artificial insemination, some constituents of the semen diluent, e.g. egg yolk, skimmed milk, buffer solutions, antibiotics, must also be considered as possible sources of antigens (Griffin, Nunn \& Hartigan, 1971; Coulter, Foote, Schiavo \& Braun, 1976). Whereas the pig female genital tract is usually cleared of seminal components within a short time after deposition (Hunter, 1975), the contact between the conceptus and the mother is much more intimate and, in pigs, lasts for nearly 4 months. The embryonic tissues must therefore be considered as a more substantial immunological challenge.

One hypothesis which has been proposed to explain the non-rejection of the feto-placental unit is the absence or the masking of transplantation antigens on the embryo and its surrounding membranes. Indeed, early studies failed to identify MHC antigens on mouse ova and preimplantation embryos. However, more direct approaches and refined techniques showed that small amounts of H-2 molecules are present on 8-cell embryos (Krco \& Goldberg, 1977) and blastocysts (Searle, Sellens, Elson, Jenkinson \& Billington, 1976). It seems that these antigens disappear from the trophoblast around the time of implantation while they are continuously expressed on the inner cell mass (Hảkansson \& Sundqvist, 1975; Searle et al., 1976). Minor transplantation antigens, e.g. H-3, H-6 and H-Y, have also been observed on preimplantation mouse embryos (Krco \& Goldberg, 1976; Muggleton-Harris \& Johnson, 1976; Billington, Jenkinson, Searle \& Sellens, 1977; Heyner, Hunziker \& Zink, 1980; Epstein, Smith \& Travis, 1980). Paternally derived $\boldsymbol{\beta}_{2}$-microglobulin has been located on mouse embryos as early as the 2-cell stage (Sawicki, Magnuson \& Epstein, 1981). Expression of $\beta_{2}$-microglobulin on preimplantation pig embryos was investigated at the ultrastructural level from the 4-cell stage until the beginning of elongation (Day 12) by using peroxidase or colloidal gold as labels (Meziou, Chardon, Fléchon, Kalil \& Vaiman, 1983). Detection of $\beta_{2}$-microglobulin was found to parallel trophoblast differentiation. No positive reaction was obtained before the early blastocyst stage (Day 6 ) while consistent staining was observed on the apical surface of the trophectoderm beyond this time. Since $\beta_{2}$-microglobulin is not only linked to 
Class $1 \mathrm{MHC}$ molecules but also to some other histocompatibility antigens the significance of this observation has yet to be determined.

In the early postimplantation period non-MHC antigens have been described on trophoblast giant cells of the mouse placenta (Sellens, Jenkinson \& Billington, 1978; Carter, 1978). After the definitive placenta is established H-2 antigens have been observed on placental cells, although their location in the labyrinthine- and spongio-trophoblast remains controversial (Jenkinson \& Owen, 1980; Chatterjee-Hasrouni \& Lala, 1982). Class II MHC antigens have not been identified on pre- and post-implantation embryonic and trophoblastic tissue (Jenkinson \& Searle, 1979; Chatterjee-Hasrouni \& Lala, 1981).

In the human placenta HLA Class 1 molecules are present on the non-villous cytotrophoblast and cells and vascular endothelium of the mesenchymal stroma of chorionic villi (Faulk, Sanderson \& Temple, 1977; Sunderland, Redman \& Stirrat, 1981; Chatterjee-Hasrouni, Montgomery \& Lala, 1983), although these may not necessarily be 'classical' class I transplantation antigens (see Johnson, 1985). Brami et al. (1983) also describe Class II antigens on disaggregated cultured human villous trophoblast cells, but not on cells in intact tissue section preparations.

Besides the expression of histocompatibility antigens, embryonic and extra-embryonic tissues carry tissue-specific antigens (Gachelin, Fellous, Guénet \& Jacob, 1976; Searle, Billington, Whyte \& Loke, 1981). On the placental trophoblast of the pig an antigen has been observed which was absent from a number of different pig tissues as well as trophoblast material of various other species (Whyte, Bacon \& Ellis, 1984). Because of its location on the microvillous border of the trophectoderm, i.e. in direct contact with maternal tissue, and its presence during all stages of gestation studied (Days 9-66), an immunoregulative role has been suggested. This antigen is obviously not secreted, and seems not to be identical with uteroferrin or placental alkaline phosphatase.

Despite sufficient evidence that Class I MHC molecules and tissue-specific antigens are expressed on human, mouse and perhaps pig conceptuses, the possibility remains that they are in some way masked, or presented, in a manner which reduces their immunogenicity. Among the substances and mechanisms advanced to account for this effect, the existence of a protective mucopolysaccharide layer on the surface of trophoblast cells (Kirby, Billington, Bradbury \& Goldstein, 1964), the constitution of an immunological buffer zone between maternal and fetal tissues by various placental products (Amoroso \& Perry, 1975) and masking of paternal MHC antigens by antibodies (Voisin \& Chaouat, 1974), transferrin (Faulk \& Galbraith, 1979) or uteroglobin (Mukherjee, Laki \& Agrawal, 1980) have been suggested.

In addition to these postulated local mechanisms, it is necessary to consider the effects of transplacental cellular traffic from the fetus to the mother, which is now well established in man (Herzenberg, Bianchi, Schröder, Cann \& Iverson, 1979) and mouse (Philip, Ayraud \& Masseyeff, 1982). Chromosome analysis of pigs revealed that male metaphases regularly constitute $1-4 \%$ of all metaphases of peripheral blood leucocytes in pregnant gilts between Weeks $2 \cdot 5$ and 6 of pregnancy. As the examination of blood from 3 virgin pigs and a pregnant sow carrying only female conceptuses showed no male mitotic figures, it was concluded that these cells are due to transplacental migration and not due to chimaerism. Fetal lymphocytes have also been described for pregnant cattle and rabbits, and it appears that the transplacental transfer of blood cells may represent a general phenomenon which is not directly related to the histological structure of the placenta (Rudek \& Kwiatkowska, 1983). However, it is not known whether these cells express transplantation antigens and therefore represent an antigenic challenge to the maternal organism.

\section{The maternal immune response towards the conceptus}

The lymph drainage of the pig uterus is anatomically represented by an extended network of lymphatic vessels within the mesometrium. Afferent vessels join in larger ducts and then drain alongside the uterine artery towards the iliofemoral node or follow the ovarian artery and deliver 
lymph to the uterine node situated within the broad ligament. The latter node also receives lymph from the ovary.

As in other species, the reproductive tract of the female pig is equipped with an effective mucosal immune system (Hussein, Newby \& Bourne, 1983a). Immunoglobulin-containing plasma cells were detected in the lamina propria at all levels of the genital tract with IgA-producing cells as the predominant type. Larger numbers of plasma cells were present in the lower parts of the tract and the number of these cells was markedly increased during oestrus. In the endometrium lgGpositive cells prevailed, and IgG was the predominant immunoglobulin in the epithelium and the interstitium of all tissues. From these results and the quantification of immunoglobulins in uterine secretions (Hussein, Newby, Stokes \& Bourne, 1983b) it appears that a limited but significant degree of immunoglobulin synthesis and release occurs locally.

The ability of the maternal immune system to mount an effective immune response against skin allografts placed in utero has been convincingly demonstrated by the extensive studies of Beer \& Billingham (1974, 1976). Leucocytes (neutrophils, macrophages and lymphocytes) enter the uterine lumen by passing through the basal lamina and squeezing between epithelial cells (McRae, 1984). That the uterus is not a privileged site for the survival of the conceptus has been shown by the continuing development of trophoblastic tissue when transplanted to ectopic sites in various species including the pig (Samuel, 1971).

A humoral immune response towards antigens of the conceptus has been described in a number of studies of man, mice and rats. These antibodies are directed against MHC, non-MHC and placental antigens and have leucoagglutinating and lymphocytotoxic properties, or react with antigens in the cytoplasm of the trophoblast (see Gill \& Repetti, 1979). Antibodies against paternal alloantigens have also been described for the horse (Allen, 1979) and cattle (Newman \& Hines, 1980). Lymphocytotoxic antibodies have been detected in the serum of $95 \%$ of sows and were often present at the same time in the colostrum. In $67 \%$ of the animals these antibodies were directed against the group A antigen, a minor transplantation antigen which is not only present on lymphocytes but also on erythrocytes. However, because the distribution of the A antigen is ubiquitous, antibody production may not necessarily be induced by pregnancy. Nevertheless, antibodies against other lymphocyte antigens were detected in $28 \%$ of the sows and in some animals were already detectable after the first pregnancy. Despite a possible immunological reaction between lymphocyte antigens of the conceptus and the corresponding antibodies, there was no evidence for any deleterious effect on the growth and the resistance of the piglets (Schmid, Cwik, Kräusslich, Meyer \& Graf zu Dohna, 1978).

From studies of Rhesus disease in man, it is well known that the maternal immune response under certain conditions can be harmful to the fetus. A similar antibody-induced damage of erythrocytes and platelets in piglets has been observed after immunization of pregnant sows by paternally derived antigens (see Linklater, 1975; Kagota, Abe \& Tokoro, 1982). In contrast to the findings in man showing that the antibodies pass through the placenta during gestation, immunoglobulins in the pig cannot cross the epitheliochorial placenta (Rejnek \& Prokesovà, 1973) and thus thrombocytopenic purpura or haemolytic disease in piglets develop only after birth, as a consequence of the transfer of antibodies with the colostrum.

Marrable (1968) described large numbers of lymphoid cells in the ischaemic extremities of the allanto-chorionic sacs of the pig placenta as well as the adjacent uterus and suggested that this may reflect immunological reactions between the sow and her conceptuses. These studies have largely been confirmed by Flood (1973), although this author considered the lymphoid-like cells in the necrotic tips of the allanto-chorion to be the remains of nucleated fetal erythrocytes. He also found large numbers of lymphocytes and plasma cells in the lamina propria of the placental and interlocular zone of the endometrium. In addition, a large concentration of eosinophils was found in the interlocular tissue, but was never seen in the placental or unoccupied parts of the uterine epithelium.

Cell-mediated immunity to paternal alloantigens, as determined by the cytotoxicity of maternal 
cells against cultured fetal calls, the mixed lymphocyte reaction, skin graft rejection, the leucocyte migration test, graft-versus-host response, and adoptive transfer tests, has been described in human as well as animal studies (see Carter, 1984). Although a few investigators failed to demonstrate any cellular immune response directed against semiallogeneic fetuses in murine pregnancies (Wegmann, Waters, Drell \& Carlson, 1979), from the above studies it seems that at least some sub-populations of lymphocytes can be sensitized against paternal antigens. However, the maternal immune reaction towards the conceptus apparently does not regularly include the development of cytotoxic antibodies and cytotoxic T-cells. On the contrary, the challenge of pregnant females with paternal alloantigens may result in a diminished MLR or graft rejection. Since this hyporesponsiveness increases with parity and is selective for alloantigens of the conceptus, specific antipaternal immuno-protective mechanisms have been proposed (see Hogarth, 1982; Carter, 1984; Head \& Billingham, 1984; Sargent \& Redman, 1985). The main candidates for such an effect are 'blocking' or 'enhancing' antibodies which may act on the target cells by masking the foreign antigens, inducing antigen shedding from the cell surface and thus preventing recognition, or by inhibition of the host's lymphocyte response presumably by the formation of antigen-antibody complexes (see Bernard, 1977). In addition, the production of auto-anti-idiotypic antibodies which bind to the receptors of lymphocytes specific for fetal MHC antigens is conceivable (Suciu-Foca, Reed, Rohowsky, Kung \& King, 1983). These antibodies ideally belong to a non-complement-fixing and therefore non-cytotoxic immunoglobulin subclass (Bell \& Billington, 1980). Besides, the maternat immune response during pregnancy appears to be regulated by suppressor cells specific for paternal alloantigens (Chaouat \& Voisin, 1979, 1980).

\section{Immunoregulation during pregnancy}

From the above account it appears that although the conceptus possesses antigenic structures on its surface which are accessible to and frequently elicit responses from the maternal immune system, there are normally no adverse effects on pregnancy. In nulliparous sows the active immunization with boar spermatozoa has been shown to have no deleterious effect on fertility or the number of live born piglets in the first litter. An increased number of stillborn young was recorded only after the second pregnancy, if the pigs were regularly reimmunized during gestation (Veselský, Staněk \& Hradecký, 1981). Even under extreme artificial conditions, when a recipient has been hypersensitized against alloantigens of a completely unrelated embryo, implantation and survival of the conceptus is not prevented, although genetically identical intrauterine skin grafts will be readily destroyed (Beer \& Billingham, 1974, 1976; Head \& Billingham, 1984). Since blocking antibodies and 'classical' suppressor cells are hardly demonstrable during a first pregnancy, other mechanisms must be involved in the immunological survival of the conceptus. In the mouse a second type of non-antigen specific suppressor cells, which inhibit the afferent and efferent phase of the graft rejection response has been described in the decidua and in the lymph nodes draining the uterus in allogeneic and syngeneic matings and during pseudopregnancy (see Clark \& McDermott, 1981; Clark, Slapsys, Croy \& Rossant, 1984). However, the significance of these cells in vivo has to be established because most of the work has been done in a limited number of different mouse strains and other investigators have failed to confirm these findings (Gottesman \& Stutman, 1981).

A general suppression of the maternal immune response during pregnancy has been suggested on the basis of observations that the lympho-myeloid system of the female undergoes striking alterations during gestation, and that in pregnant women there is a reduced resistance against certain virus diseases, the survival time of skin grafts is prolonged and the tuberculin reaction is depressed (see Carter, 1984). However, on the whole, these effects are minimal and occur too late in gestation to be of major significance for the survival of the fetus (Head \& Billingham, 1984). With in-vitro test systems (MLR, mitogen induced lymphocyte transformation), conflicting results have been achieved. While many investigators reported a diminished responsiveness of maternal lymphocytes 
(Finn et al., 1972; Purtilo, Hallgren \& Yunis, 1972; Stahn, Fabricius \& Hartleitner, 1978; Burrells, Wells \& Sutherland, 1978), others reached different conclusions (Birkeland \& Kristofferson, 1980a, b, c; Miyasaka \& McCullagh, 1981). Similarly, there have been numerous yet conflicting communications on the distribution, relative number and proportion of different classes and sub-classes of lymphocytes during pregnancy (see Carter, 1984). It has been claimed that T-cells bearing receptors for the Fc portion of $\operatorname{IgM}(\mathrm{Fc} \mu)$ and those bearing $\mathrm{Fc}$ receptors for $\operatorname{IgG}(\mathrm{Fc} \gamma)$ belong to different sub-populations, the former being helper cells and the latter suppressor cells (Moretta, Ferrarini, Mingari, Moretta \& Webb, 1976). Accepting this discrimination, a considerable increase of T $\gamma$-cells occurred in the blood and in the lymph nodes draining the uterus during pregnancy in the pig. Cell numbers were relatively higher at the beginning of pregnancy (Days 20-40) and lower at the end (Days 80-110), while no significant quantitative change was found in T $\mu$ cells. During pregnancy there was also a marked drop in the number of haemolytic plaque-forming cells (Georgieva, 1984). These results, however, must be treated with caution since it has been demonstrated that $\mathrm{T} \mu$ cells may not only include helper T-cells but also suppressor T-cells, and T $\gamma$-cells comprise cells from the monocyte lineage (Reinherz et al., 1980).

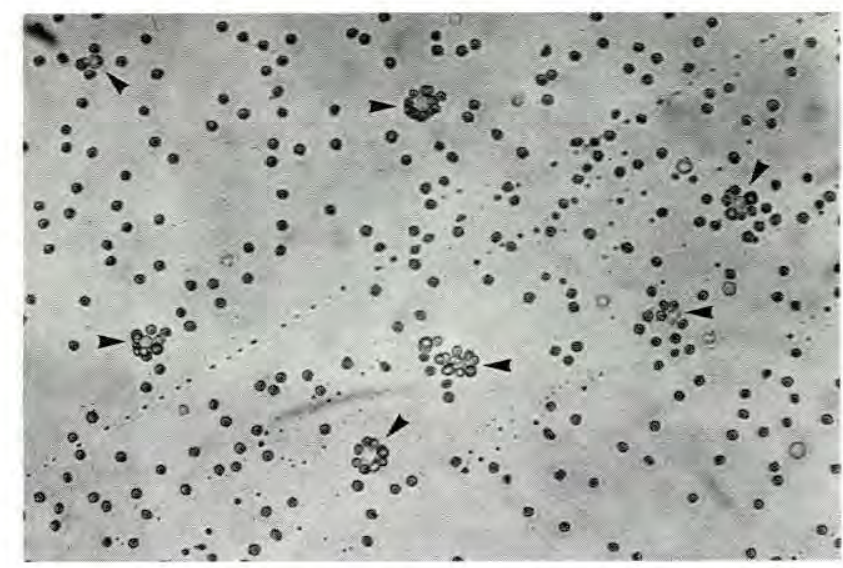

Fig. 1. Formation of spontaneous rosettes (arrowed) between pig lymphocytes and sheep red blood cells. $\times 320$.

T-lymphocytes of many species are characterized by their ability to bind sheep red blood cells, and thus form cell clusters known as spontaneous or E-rosettes (Fig. 1). This rosette formation can be inhibited by several compounds including antilymphocyte serum (Bach \& Antoine, 1968) and immunosuppressive drugs (Bach, Dardenne \& Fournier, 1969a), and it has been demonstrated that the immunosuppressive effect of an antilymphocyte serum, as measured by the survival time of skin grafts, is closely correlated to its rosette-inhibiting activity (Bach, Dormont, Dardenne \& Balner, 1969 b). Using lymphocytes from different donors the titre to which an antilymphocyte serum reduces the rosette number by at least $25 \%$ (rosette-inhibition titre, RIT) does not significantly vary. However, if lymphocytes have already been exposed to immunosuppressive reagents, the RIT of a particular serum is much higher (Munro et al., 1971). Applying the rosette-inhibition test, Morton, Hegh \& Clunie (1974) discovered that rosettes formed with lymphocytes from pregnant mice during the first 2 weeks of gestation could be inhibited with significantly lower dilutions of a standard antilymphocyte serum when compared to lymphocytes of non-pregnant animals. Since this reaction occurred within 4-6h after mating and could also be induced with normal lymphocytes after preincubation in pregnancy serum (Morton, Hegh \& Clunie, 1976), they postulated a 


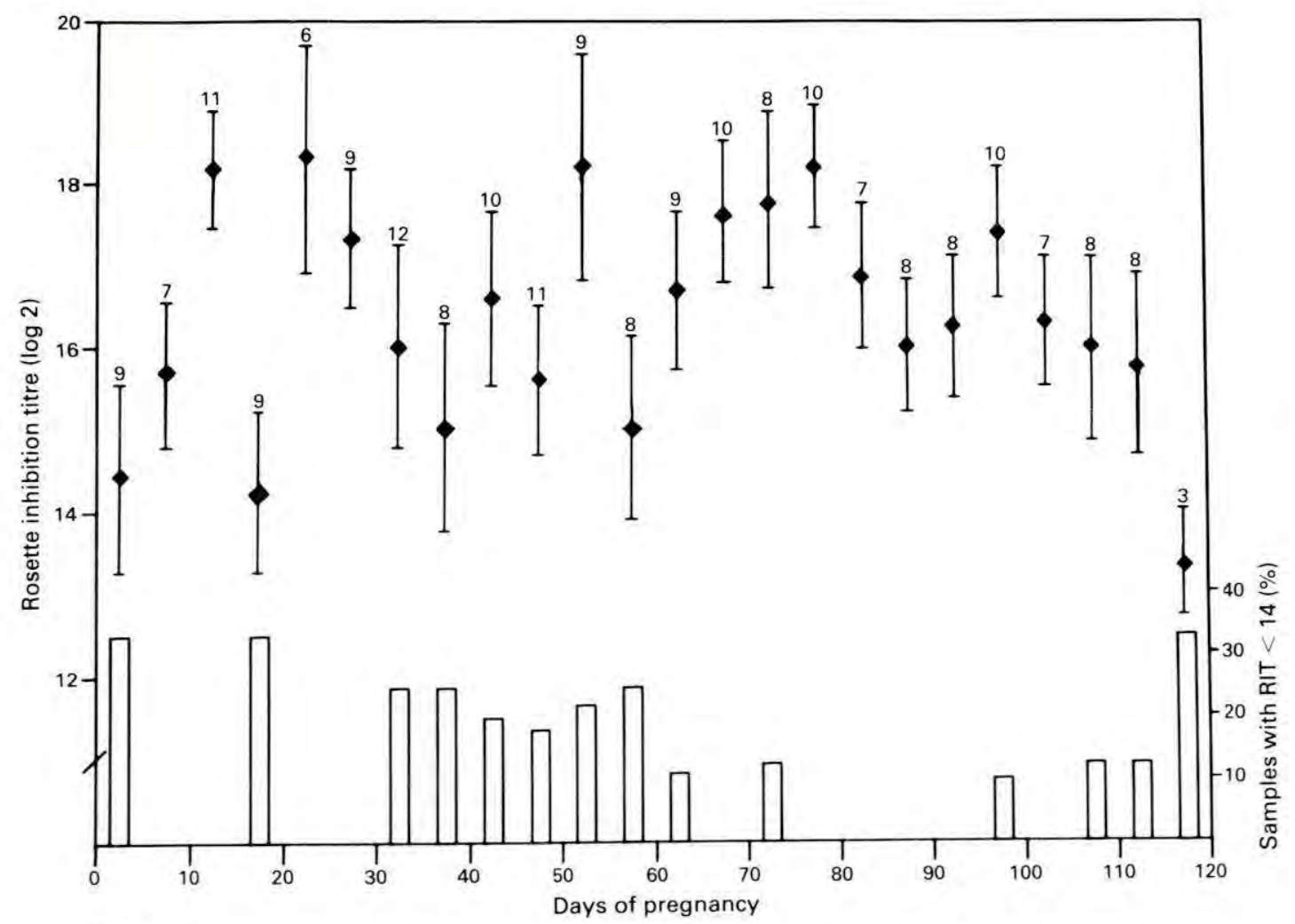

Fig. 2. Serum rosette inhibition titres (RIT) during pregnancy in the pig. Serum samples were collected from 205 sows between Days 1 and 118 of pregnancy. Each point summarizes 5 consecutive days of pregnancy and represents the mean \pm s.e.m. for the number of animals indicated. The percentage of pigs without detectable EPF activity is given in the histograms: an RIT of at least 14 indicates EPF activity.

pregnancy-dependent serum constituent which later was termed early pregnancy factor (EPF) (Morton, Rolfe, Clunie, Anderson \& Morrison, 1977). EPF has also been described in humans (Morton et al., 1977; Smart, Roberts, Fraser, Cripps \& Clancy, 1982), sheep (Morton, Nancarrow, Scaramuzzi, Evison \& Clunie, 1979), rats (Heywood, Goodall \& Thorburn, 1979), cattle (Nancarrow, Wallace \& Grewal, 1981; Georgieva \& Stefanov, 1984), pigs (Paisley, Davis, Anderson \& Mickelsen, 1982; Morton, Morton \& Ellendorff, 1983; Georgieva \& Stefanov, 1984; Grewal et al., 1985) and giant pandas (Meuli, Kleiman \& Bush, 1984).

In the pig, EPF has been demonstrated within $4-6 \mathrm{~h}$ after mating in individual sows and was present in all pregnant animals $24 \mathrm{~h}$ post coitum. While in all other species studied EPF was detectable only during the first half or two-thirds of pregnancy, in pigs it is present until the time of parturition but displays characteristic fluctuation in the course of gestation (Fig. 2) (Koch, Morton, Morton \& Ellendorff, 1982; Morton et al., 1983; Koch, Morton \& Ellendorff, 1983; Koch \& Ellendorff, 1985a).

During the preimplantation stages of pregnancy EPF is thought to be produced by the oviduct and ovary in response to an initial signal from the embryo and the continued presence of a viable conceptus (Cavanagh, Morton, Rolfe \& Gidley-Baird, 1982). However, EPF-like activity has been detected in the seminal plasma of boars and there is some evidence that this activity can be detected in the circulation of females for about $24 \mathrm{~h}$ after mating with a vasectomized boar (Koch \& Ellendorff, 1985b). Nevertheless, the sustained production of EPF in the pig seems to depend on 
the presence of fertilized ova, because EPF activity has been observed within $2-4 \mathrm{~h}$ after embryo transfer and disappeared $24 \mathrm{~h}$ after the removal of conceptuses (E. Koch, H. Niemann \& F. Ellendorff, unpublished observation). From implantation onwards embryonic tissue itself appears to achieve the ability to produce EPF (Morton, Rolfe \& Cavanagh, 1982a). In addition, EPF activity has been detected in the serum of patients with certain germ cell tumours (Rolfe, Morton, Cavanagh \& Gardiner, 1983a), leading to speculation that EPF might be an onco-developmental protein (see Whyte \& Heap, 1983).

Maternal, fetal and tumour EPF are of similar molecular size, exhibit immunological crossreactivity and give the same response in the rosette-inhibition test, but preliminary studies have suggested that they may differ in some biochemical characteristics. From these investigations it appears that EPF represents a protein with a monomeric size of 20000-21 000 which can form dimers and polymers. Maternal EPF has been found to bind to a protein carrier, present in normal serum, and can be further separated by $40 \%$ ammonium sulphate into two components, termed EPF-A and EPF-B. Both compounds have a similar molecular weight of about 10000 and alone do not exhibit any EPF activity in the rosette-inhibition test. EPF-A seems to be identical with the product released from the oviduct while EPF-B expresses activity similar to the ovarian component (Wilson, McCarthy \& Clarke, 1983, 1984; Cavanagh, 1984; Morton, 1984).

Because of the interaction between EPF and some ALS, an immunosuppressive function has been proposed for EPF. To test this hypothesis in vivo the technique of adoptive transfer of contact sensitivity against trinitrochlorobenzene (TNCB) has been applied (Noonan, Halliday, Morton \& Clunie, 1979). Lymphocytes of sensitized mice were incubated in serum or serum fractions of pregnant and nonpregnant sheep before the injection into naive syngeneic recipients. With all serum samples from pregnant sheep, in which EPF activity had been detected by the rosetteinhibition test, the delayed-type hypersensitivity reaction was markedly reduced after exposing the recipients to TNCB. These experiments have been repeated using partly purified human and mouse EPF (Rolfe, Morton \& Clarke, 1983b; Morton, 1984), and the results have been interpreted as suggesting that EPF exerts an immunosuppressive effect by preventing antigen recognition by sensitized T-lymphocytes. It is now believed that EPF binds in a non-species-specific manner to a very small percentage of lymphocytes which in turn express a genetically restricted suppressor activity responsible for the observed effects in the rosette-inhibition test and the adoptive transfer of contact sensitivity (Morton, 1984).

It should be emphasized that the demonstration of the total population of rosette-forming cells (T-RFC) requires the incubation of lymphocytes with sheep red blood cells for at least $60 \mathrm{~min}$, while a small proportion of 'active' T-cells forms rosettes within 5 min (Wybran, Levin, Spitler \& Fudenberg, 1973). Only these active rosette-forming cells (A-RFC) respond in the rosette-inhibition test (Morton, Tinneberg, Rolfe, Wolf \& Mettler, 1982b). The kinetics of the A-RFC response in humans closely paralleled the delayed-type hypersensitivity reaction to different microbial antigens, with the number of these cells varying independently of the T-RFC population (Felsburg, Edelman \& Gilman, 1976). It is thought that these cells represent a distinct subset of T-lymphocytes related to the cellular immune status of patients as assessed by other in-vivo and in-vitro methods (Wybran et al., 1973). The rosette-inhibition test therefore appears to detect a sub-population of T-lymphocytes which is similar or identical to the delayed-type hypersensitivity T-cells, the possible effector cells of allograft rejection.

Criticism of the function and existence of EPF is mainly based on the absence of a reference compound as well as a reliable in-vitro test system (Whyte \& Heap, 1983), while the failure of some groups to detect an inhibition of rosette formation during human pregnancy (Thomson, Milton, Campbell \& Horne, 1980; Cooper \& Aitken, 1981) seems to derive from technical differences (Morton et al., 1982b; Smart et al., 1982).

A large number of other substances have been suggested to be of importance for the immunological protection of the conceptus (Table 1). However, like EPF the relevance of these compounds for the survival of the fetus and in different species has to be established. Indeed, considering 
the multitude of possible immunosuppressants during gestation, it is difficult to imagine how a pregnani female is still able to mount an effective immune response to infections or to experimental allografts. However, a possible explanation for this dilemma might be that all these substances mainly express their immunosuppressive effects locally at the feto-maternal interface or regionally in the lymph system draining the uterus. The demonstration of immunosuppressive properties of seminal plasma (see James \& Hargreave, 1984), uterine secretory proteins (Roberts, 1977; Murray, Segerson \& Brown, 1978; Allen, Murray \& Wietsma, 1981; Segerson, 1981) and allantoic and amniotic fluids (Murray, Zurcher \& Grifo, 1979) supports the idea of a localized protective mechanism from the time of copulation until the termination of gestation. The active material in pig uterine secretory fluids is thought to be a group of progesterone-induced acidic proteins (Etzel, Murray, Grifo \& Kinder, 1978; Murray et al., 1978; Allen et al., 1981), while the main factor responsible for the suppressive effect of pig allantoic and amniotic fluid might be $\alpha$-fetoprotein (AFP), although allantoic fluid presumably also contains proteins secreted by the uterus (Murray $e t$ al., 1979).

Table 1. Some substances with supposed immunoregulative function during pregnancy (prepared from Gill \& Repetti, 1979; Hogarth, 1982; Carter, 1984)

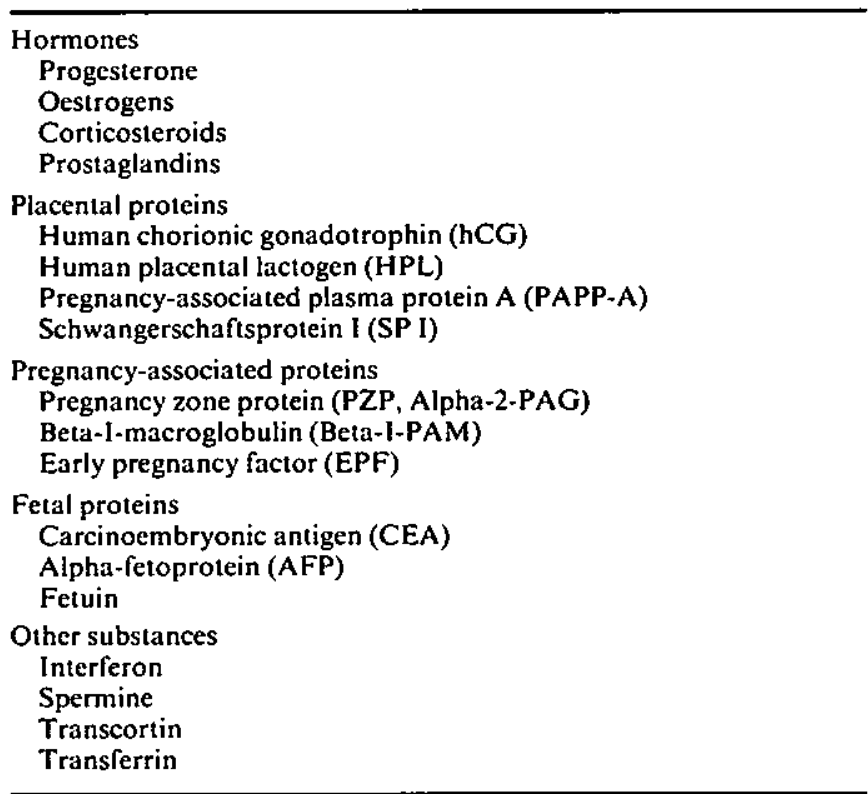

\section{Histoincompatibility and reproductive performance}

As indicated by the occurrence of blocking antibodies and suppressor celis (see above) the antigenic disparity between mother and fetus might not only be harmless but in certain circumstances even beneficial for implantation and continued intrauterine development of the offspring (see Gill \& Repetti, 1979). Indeed, several investigators have reported an increased number of conceptuses, a higher mean placental weight and an improved fetal growth rate in allogeneic as compared to syngeneic matings (Billington, 1964; James, 1965, 1967; Beer \& Billingham, 1974; Beer, Billingham 
\& Scott, 1975). Previous active or passive immunization of the mother against paterna! antigens further enhanced these effects, while the induction of tolerance had a negative influence (James, 1965, 1967; Beer et al., 1975). In rats and mice removal of the lymph nodes draining the uterus was followed by a significant decrease in litter size, an uneven development of fetuses within the uterus and a reduced placental and fetal weight (Beer et al., 1975; Tofoski \& Gill, 1977). Beer et al. (1975) also demonstrated that presensitization of female rats in one uterine horn by a skin graft from a different strain improved the reproductive efficiency, with significantly more fetuses implanting in the immunized horn than in the contralateral unsensitized horn. The immunological basis of this observation was strengthened by the fact that syngeneic fetuses did not enjoy any advantage with regard to numbers present over those in the non-immunized uterine horn.

Based on some of the above observations, Clarke \& Kirby (1966) put forward the hypothesis that polymorphism of histocompatibility antigens might be maintained by favouring antigenically dissimilar rather than histocompatible conceptuses. However, this theory has been severely criticized (McLaren, 1975) on the basis of a number of observations which showed that antigenic disparity or previous immunization against paternal antigens either had no effect at all or were even detrimental, as they decreased litter size, fetal survival or conceptus weight (Breyere \& Sprenger, 1969; Clarke, 1969, 1971; Hetherington, 1973; Hetherington \& Fowler, 1978; Auerbach, Hay \& Kubai, 1980) and therefore most of the advantages of the hybrid fetus are related to aspects of heterosis other than immunological mechanisms.

Despite these reservations and the equivocal nature of the results reviewed above, there are further observations which suggest that an immunological component may provide an advantage for those fetuses which are histoincompatible with the dam. If backcrosses are performed between an $F_{1}$ individual and one parent of the original inbred strain, half of the offspring should be homozygous while the other half are expected to be heterozygous with respect to the differences at any gene locus. However, in the case of differences at the MHC loci the situation is complicated because all offspring from $F_{1}$ females are histocompatible with the mother, while in the reciprocal situation $50 \%$ of the fetuses will be histoincompatible (Fig. 3). Employing a related mating scheme, a few reports have described an excess of heterozygous progeny if an inbred female rat or mouse was mated to an $F_{1}$ male, but not in the reverse mating (Hull, 1969; Palm, 1974; Hamilton \& Hellström, 1978). As all heterozygous fetuses should benefit from heterosis in the same manner, independent of the uterine environment, the deviation from the normal Mendelian segregation may be related to an immunological response. This explanation is supported by the observation that the selection pressure results in an increased proportion of heterozygous fetuses with subsequent litters, possibly due to sensitization in previous pregnancies. In the rat the number of progeny compatible with their mother at the MHC is apparently reduced in the prenatal and postnatal periods by a maternally induced graft-versus-host reaction directed against minor histocompatibility antigens (Palm, 1974). Since in the mouse no reduction in the litter size or increased postnatal death was observed, selective fertilization, or more probably favoured implantation, of histoincompatible fetuses appears to be involved (Hamilton \& Hellström, 1978). A similar observation has been made in the pig. Mating between two parents typed for swine lymphocyte antigen, which shared one haplotype but were different at the second one, resulted in 8 haplotypes with the expected equal distribution of the four possible genotypes, but in one haplotype the number of homozygous piglets was significantly lower than expected (Vaiman \& Renard, 1980). In man, histocompatibility between husband and wife at the HLA loci has been suggested as a determinant of recurrent spontaneous abortion, but this concept has been questioned by others (Caudle, Rote, Scott, DeWitt \& Barney, 1983). Despite this controversy several groups have now reported successful pregnancies after maternal immunization with unrelated or paternal leucocytes, although this treatment seems to include a considerable risk of intrauterine growth retardation and other malformations (see Johnson, 1985).

Murray, Grifo \& Parker (1983) induced a type of local immunity in gilts in order to increase the litter size. In the first experiment, uterine exposure to fresh diluted or freeze-thawed semen of 4 
Female Male

$A B \times A A$

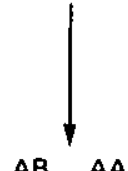

AB AA

No histoincompatibility between mother and fetuses
Female Male

$A A \times A B$

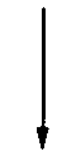

AB AA

Histoincompatibility between mother and heterozygous fetuses

Fig. 3. Reciprocal backcrosses between an $F_{1}$ parent and a mate from one of the original inbred lines. A and B represent two different MHC haplotypes (adapted from Hamilton \& Hellström, 1978).

boars was performed 3 times at least at 3-week intervals, while control animals received saline infusions. All sows were subsequently inseminated with semen from one of the boars used for treatment. At farrowing, significantly more piglets per litter were produced by the semen-treated as compared to the control animals $(10.35$ vs 8.39). However, the number of live-born piglets and the litter size at 2 weeks were not different, although this was attributed to an outbreak of porcine parvovirus infection in the herd. For the second litter, produced by different boars of the same breed, no difference in reproductive performance was observed. In two subsequent studies sows were treated twice at oestrus with an intrauterine infusion of freeze-thawed, pooled semen and later mated by one of the boars used as a semen donor. Although pigs in both experimental groups had a larger litter size than untreated control animals, this effect was not statistically significant.

Skjervold, Almlid, Onstad \& Fossum (1979) listed several observations with regard to animal reproduction which are thought to support the theory that immunological stimuli might influence the reproductive performance of females. These authors referred to results obtained in experiments with heterospermic insemination, the comparison of the heterosis effect and the litter size after natural and artificial insemination, as well as the effect of the sire on the litter size, which all suggest that the qualitative and quantitative aspects of the 'antigenic dose' introduced into the uterus during mating may interfere with fecundity. Consequently these investigators studied the effect of adding cellular antigens to the semen of boars on the reproductive performance of pigs. Gilts were inseminated with normal semen or semen containing $2 \times 10^{8}$ leucocytes from the same boar, an unrelated pig, or cattle. The average number of normal embryos was increased in all experimental groups at autopsy during the '5th week after insemination, but this increase was not statistically significant. When the results from all experimental groups were pooled, the number of normal embryos adjusted for ovulation rate was significantly increased by $12.4 \%$ ( $1 \cdot 2$ piglets) as compared to the control group (Almlid, 1981).

While the above-cited experiments do not conclusively indicate whether histoincompatibility between mother and conceptus influences the reproductive performance of females, at least some aspects of the maternal-fetal interrelationship appear to be beneficially influenced by antigenic disparity. The immunological component of this reaction, however, has to be established in further studies.

\section{Conclusions}

The literature dealing with immunological aspects of mammalian reproduction is extensive, frequently contradictory and mainly based on human and rodent studies, while information available on other species is very sparse. In the search for generally valid concepts it seems therefore 
appropriate to consider also other animal models. The pig offers a number of interesting features which make it a suitable candidate for such investigations. First of all, the epitheliochorial pig placenta represents a much more substantial anatomical barrier when compared with other forms of placentation. Moreover, only oestrogens have been definitively described as endocrine products of the pig placenta, challenging the concept of an hormonally induced immunological buffer zone at the interface between maternal and fetal tissues (Heap, Flint \& Staples, 1983). For experimental work the pig uterus and the draining lymph system have the advantage of easy access. Because of the size of the female genital tract and the conceptuses, manipulations as well as collection of material are readily feasible, and the large litter size allows simultaneous studies on different fetuses within a single animal. Finally, knowledge of the endocrine regulation of the reproductive processes and the anatomical and cellular constitution of the immune system, as well as the genetic and biochemical basis of the immune response is considerable.

Besides the scientific interest in the pig as an animal model for studies in reproductive immunology, these investigations might also be of practical relevance. Embryonic mortality in the pig is high and many possible causes have been discussed (see Flint, Saunders \& Ziecik, 1982). Immunological factors, however, have hardly been considered so far. In addition to the prevention of embryonic failure, there is evidence that immunological interventions might actively be applied to increase prolificacy, while some of the factors discussed in connection with the immunoprotection of the conceptus could prove to be valuable indicators for pregnancy diagnosis and the continuing monitoring of embryonic viability.

I am most grateful to $\operatorname{Dr} \mathrm{R}$. B. Heap for his advice and criticism in the preparation of this review and to Mrs J. A. Tickner for typing the manuscript.

\section{References}

Allen, R.L., Murray, F.A. \& Wietsma, H.T. (1981) Immunosuppression in the mouse by porcine uterine secretory protein. Am. J. reprod. Immunol. 1, 193-198.

Allen, W.R. (1979) Maternal recognition of pregnancy and immunological implications of trophoblastendometrium interactions in equids. In Maternal Recognition of Pregnancy (Ciba Fdn Symp. No. 64), pp. 323-346. Ed. J. Whelan. Excerpta Medica, Amsterdam.

Almlid, T. (198I) Does enhanced antigenicity of semen increase the litter size in pigs? Z. tierzücht. Züchtgsbiol. 98, 1-10.

Amoroso, E.C. \& Perry, J.S. (1975) The existence during gestation of an immunological buffer zone at the interface between maternal and foetal tissues. Phil. Trans. R. Soc. Lond. B 271, 343-361.

Auerbach, R., Hay, J.B. \& Kubai, L. (1980) Fetomaternal histoincompatibility and placental blood flow. J. Physiol., Lond. 307, 465-474.

Bach, J.F. \& Antoine, B. (1968) In vitro detection of immunosuppressive activity of anti-lymphocyte sera. Nature, Lond. 217, 658-659.

Bach, J.F., Dardenne, M. \& Fournier, C. (1969a) In vitro evaluation of immunosuppressive drugs. Nature, Lond. 222, 998-999.

Bach, J.F., Dormont, J., Dardenne, M. \& Balner, $\mathbf{H}$. (1969b) In vitro rosette inhibition by antihuman antilymphocyte serum. Correlation with skin graft prolongation in subhuman primates. Transplantation 8, 265-280.
Beer, A.E. \& Billingham, R.E. (1974) Host response to intra-uterine tissue, cellular and fetal allografts. $J$. Reprod. Fert., Suppl. 21, 59-88.

Beer, A.E. \& Billingham, R.E. (1976) The Immunobiology of Mammalian Reproduction. Prentice-Hall, Englewood Cliffs.

Beer, A.E., Billingham, R.E. \& Scott, J.R. (1975) Immunogenetic aspects of implantation, placentation and feto-placental growth rates. Biol. Reprod. 12, 176-189.

Bell, S.C. \& Billington, W.D. (1980) Major anti-paternal alloantibody induced by murine pregnancy is non-complement-fixing IgGl. Nature, Lond. 288, 387-388.

Bernard, O. (1977) Possible protecting role of maternal immunoglobulins on embryonic development in mammals. Immunogenetics 5, 1-15.

Billington, W.D. (1964) Influence of immunological dissimilarity of mother and foetus on size of placenta in mice. Nalure. Lond. 202, 317-318.

Billington, W.D., Jenkinson, E.J., Searle, R.F. \& Sellens, M.H. (1977) Alloantigen expression during early embryogenesis and placental ontogeny in the mouse: immunoperoxidase and mixed hemadsorption studies. Transplant. Proc. 9, 1371-1377.

Birkeland, S.A. \& Kristofferson, K. (1980a) A longitudinal study of $\mathrm{B}$ lymphocyte responses during human pregnancy. $J$. reprod. Immunol. 2, 23-27.

Birkeland, S.A. \& Kristofferson, K. (1980b) The fetus as an allograft: a longitudinal study of normal human pregnancies studied with mixed lymphocyte cultures 
between mother-father and mother-child. Scand. J. Immunol. 11, 311-319.

Birkeland, S.A \& Kristofferson, K. (1980c) Lymphocyte transformation with mitogens and antigens during normal human pregnancy: a longitudinal study. Scand. J. Immunol. 11, 321-325.

Brami, C.J., Sanyal, M.K., Dwyer, J.M., Johnson, C.C., Kohorn, E.I. \& Naftolin, F. (1983) HLA-DR antigen on human trophoblast. Am. J. reprod. Immunol. 3, 165-174.

Breyere, E.J. \& Sprenger, W.W. (1969) Evidence of allograft rejection of the conceptus. Transplant. Proc. $1,71-75$.

Burrells, C., Wells, P.W. \& Sutherland, A.D. (1978) Reactivity of ovine lymphocytes to phytohaemagglutinin and pokeweed mitogen during pregnancy and in the immediate post parturient phase. Clin. exp. Immunol. 33, 410-415.

Carpenter, C.B., D'Apice, A.J.F. \& Abbas, A.K. (1976) The role of antibodies in the rejection and enhancement of organ allografts. Adv. Immunol. 22, 1-65.

Carter, J. (1978) The expression of surface antigens on three trophoblastic tissues in the mouse. J. Reprod. Fert. 54, 433-439.

Carter, J. (1984) The maternal immunological response during pregnancy. In Oxford Reviews on Reproductive Biology, Vol. 6, pp. 47-I28. Ed. J. R. Clarke. Clarendon Press, Oxford.

Caudle, M.R., Rote, N.S., Scott, J.R., DeWitt, C. \& Bamey, M.F. (1983) Histocompatibility in couples with recurrent spontaneous abortion and normal fertility. Fert. Steril. 39, 793-798.

Cavanagh, A.C. (1984) Production in vitro of mouse early pregnancy factor and purification to homogeneity. $J$. Reprod. Fert. 71, 581-592.

Cavanagh, A.C., Morton, H., Rolfe, B.E. \& Gidley-Baird, A.A. (1982) Ovum factor: a first signal of pregnancy? Am. J. reprod. Immunol. 2, 97-101.

Chaouat, G. \& Voisin, G.A. (I979) Regulatory T cell subpopulations in pregnancy. 1. Evidence for immunosuppressive activity of the early phase of MLR. J. Immunol. 122, 1383-1388.

Chaouat, G. \& Voisin, G.A. (1980) Regulatory T-cell subpopulations in pregnancy, II. Evidence for suppressive activity of the late phase of MLR. Immunology 39, 239-248.

Chardon, P., Renard, C. \& Vaiman, M. (1981) Characterization of Class II histocompatibility antigens in pigs. Anim. Blood Grps biochem. Genes. 12, 59-65.

Chardon, P., Vaiman, M., Renard, C. \& Arnoux, B. (1978) Pig histocompatibility antigens and $\beta_{2}-$ microglobulin. Transplantation 26, 107-112.

Chatterjee-Hasrouni, S. \& Lala, P.K. (1981) MHC antigens on mouse trophoblast cells: paucity of la antigens despite the presence of $\mathrm{H}-2 \mathrm{~K}$ and $\mathrm{D}$. $J$. Immunol. 127, 2070-2073.

Chatterjee-Hasrouni, S. \& Lala, P.K. (1982) Localization of paternal $\mathrm{H}-2 \mathrm{~K}$ antigens on murine trophoblast cells in vivo. J.exp. Med. 155, 1679-1689.

Chatterjee-Hasrouni, S., Montgomery, B. \& Lala, P.K. (1983) Alloantigenicity of trophoblast cells. Am. J. reprod. Immunol. 3, 127-131.

Clark, D.A. \& McDermott, M.R. (1981) Active suppression of host-vs-graft reaction in pregnant mice. III. Developmental kinetics, properties, and mechanism of induction of suppressor cells during first pregnancy. $J$. Immunol. 127, 1267-1273.

Clark, D.A., Slapsys, R.M., Croy, B.A. \& Rossant, J. (I984) Immunoregulation of host-versus-graft responses in the uterus. Immanol. Today 5, $111-115$.

Clarke, A.G. (1969) Factors affecting the growth of trophoblast transplanted to the testis. $J$. Reprod. Fert. 18, 539-541.

Clarke, A.G. (1971) The effects of maternal preimmunization on pregnancy in the mouse. J. Reprod. Fert. 24, 369-375.

Clarke, B. \& Kirby, D.R.S. (1966) Maintenance of histocompatibility polymorphisms. Nature, Lond. 211 , 999-1000.

Cooper, D.W. \& Aitken, R.J. (1981) Failure to detect altered rosette inhibition titres in human pregnancy serum. J. Reprod. Fert. 61, 241-245.

Coulter, G.H., Foote, R.H., Schiavo, J.J. \& Braun, R.K. (1976) Antibodies to egg yolk in blood serum of rabbits and cattle and cervical mucus of cattle inseminated artificially. Theriogenology 6, 585-589.

Epstein, C.J., Smith, S. \& Travis, B. (1980) Expression of $\mathrm{H}-\mathrm{Y}$ antigen on preimplantation mouse embryos. Tissue Antigens 15, 63-67.

Erickson, R.P., Lewis, S.E. \& Butley, M. (198I) Is haploid gene expression possible for sperm antigens? J. reprod. Imminol. 3, 195-217.

Etzel, B.J., Murray, F.A., Grifo, A.P. \& Kinder, J.E. (1978) Partial purification of uterine secretory protein capable of suppressing lymphocyte reactivity in vitro. Theriogenology 10, 469-480.

Faulk, W.P. \& Galbraith, G.M.P. (1979) Trophoblast transferrin and transferrin receptors in the hostparasite relationship of human pregnancy. Proc. $R$. Soc. Lond. B 204, 83-97.

Faulk, W.P., Sanderson, A.R. \& Temple, A. (1977) Distribution of $\mathrm{MHC}$ antigens in human placental and chorionic villi. Transplant. Proc. 9, 1379-1384.

Felsburg, P.J., Edelman, R. \& Gilman, R.H. (1976) The active $E$ rosette test: correlation with delayed cutaneous hypersensitivity. $J$. Immunol. 116 , $1110-1114$.

Finn, R., St Hill, C.A., Govan, A.J., Ralfs, I.G., Gurney, F.J. \& Denye, V. (1972) Immunological responses in pregnancy and survival of fetal homograft. Br. med. J. 3, 150-152.

Flint, A.P.F., Saunders, P.T.K. \& Ziecik, A.J. (1982) Blastocyst-endometrium interactions and their significance in embryonic mortality. In Control of Pig Reproduction, pp. 253-275. Eds D. J. A. Cole \& G. R. Foxcroft. Butterworth, London.

Flood, P.F. (1973) Endometrial differentiation in the pregnant sow and the necrotic tips of the allantochorion. J. Reprod. Fert. 32, 539-543.

Gachelin, G., Fellous, M., Guénet, J.L. \& Jacob, F. (1976) Developmental expression of an early embryonic antigen common to mouse spermatozoa and cleavage embryos, and to human spermatozoa: its expression during spermatogenesis. Devl Biol. 50, 310-320.

Georgieva, R. (1984) Dynamics of T-suppressor and $T$-helper lymphocytes and haemolytic plaqueforming cells during normal pregnancy in the sow. $J$. reprod. Immunol. 6, 151-156.

Georgieva, R. \& Stefanov, D. (1984) Early pregnancy factor (EPF) in cows and sows. Detection of pregnancy, 
embryonic mortality and its partial characterization. Proc. IOth Int. Congr. Anim. Reprod. \& A.I. Urbana-Champaign, Vol. 2, p. 83, Abstr.

Gill, T.J. \& Repetti, C.F. (1979) Immunologic and genetic factors influencing reproduction. $A m$. J. Pathol. 95, 465-570.

Gottesman, S.R.S. \& Stutman, O. (1981) Comparison of cellular immune changes in the draining paraaortic lymph nodes in syngeneic and allogeneic pregnancies. In Reproductive Immunology, pp. 121-136. Ed. N. Gleicher. Alan R. Liss, New York.

Grewal, A.S., Wallace, A.L.C., Pan, Y.S., Rigby, N.W., Donnelly, J.B., Eagleson, G.K. \& Nancarrow, C.D. (1985) Evaluation of a rosette inhibition test for pregnancy diagnosis in pigs. J. reprod. Immunol. 7 , 129-138.

Griffin, J.F.T., Nunn, W.R. \& Hartigan, P.J. (197I) An immune response to egg-yolk semen diluent in dairy cows. J. Reprod. Ferr. 25, 193-199.

Håkansson, S. \& Sundqvist, K.G. (1975) Decreased antigenicity of mouse blastocysts after activation for implantation from experimental delay. TransplanIation 19, 479-484.

Hamilton, M.S. \& Hellström, I. (1978) Selection for histoincompatible progeny in mice. Biol. Reprod. 19 , 267-270.

Head, J.R. \& Billingham, R.E. (1984) Mechanisms of non-rejection of the feto-placental allograft. In Intmunological Aspects of Reproduction in Mammals. pp. 133-152. Ed. D. B. Crighton. Butterworth, London.

Heap, R.B., Flint, A.P.F. \& Staples, L.D. (1983) Endocrinology of trophoblast in farm animals. In Biology of Trophoblast, pp. 353-400. Eds Y. W. Loke \& A. Whyte. Elsevier, Amsterdam.

Herzenberg, L.A., Bianchi, D.W., Schröder, J., Cann, H.M. \& Iverson, G.M. (1979) Fetal cells in the blood of pregnant women: detection and enrichment by fluorescence-activated cell sorting. Proc. natn Acad. Sci. U.S.A. 76, 1453-1455.

Hetherington, C.M. (1973) The absence of any effect of maternal/fetal incompatibility at the $\mathrm{H}-2$ and $\mathrm{H}-3$ loci on pregnancy in the mouse. $J$. Reprod. Fert. 33, 135-139.

Hetherington, C.M. \& Fowler, H. (1978) Effect of tolerance to paternal antigens on placental and fetal weight in the mouse. J. Reprod. Fert. 52, 113-117.

Heyner, S., Hunziker, R.D. \& Zink, G.L. (I980) Differential expression of minor histocompatibility antigens on the surface of the mouse oocyte and preimplantation developmental stages. $J$. reprod. Immunol. 2, 269-279.

Heywood, L.H., Goodall, E.T. \& Thorburn, G.D. (1979) Detection of early pregnancy in the rat using the rosette inhibition test. Proc. Aust. Soc. Reprod. Biol. 11, 55, Abstr.

Hogarth, P.J. (1982) Immunological Aspects of Mammalian Reproduction. Blackie, London.

Howard, J.C. (1985) Immunological help at last. Nature. Lond. 314, 494-495.

Hull, P. (1969) Maternal-foetal incompatibility associated with the H-3 locus in the mouse. Heredity 24 , 203-209.

Hunter, R.H.F. (1975) Physiological aspects of sperm transport in the domestic pig, Sus scrofa. II. Regu- lation, survival and fate of cells. Br. ver. J. 131, $681-690$.

Hussein, A.M., Newby, T.J. \& Bourne, F.J. (1983a) Immunohistochemical studies of the local immune system in the reproductive tract of the sow. J. reprod. lmmunol. 5, 1-15.

Hussein, A.M., Newby, T.J., Stokes, C.R. \& Bourne, F.J. (1983b) Quantitation and origin of immunoglobulins $A, G$ and $M$ in the secretions and fluids of the reproductive tract of the sow. $J$. reprod. Immunol. 5, 17-26.

James, D.A. (1965) Effects of antigenic dissimilarity between mother and foetus on placental size in mice. Narure, Lond. 205, 613-614.

James, D.A. (1967) Some effects of immunological factors on gestation in mice. J. Reprod. Fers. 14, 265-275.

James, K. \& Hargreave, T.B. (1984) Immunosuppression by seminal plasma and its possible clinical significance. Immunol. Today 5, 357-363.

Jenkinson, E.J. \& Owen, V. (1980) Ontogeny and distribution of major histocompatibility complex (MHC) antigens on mouse placental trophoblast. $J$. reprod. Inmunol. 2, 173-181.

Jenkinson, E.J. \& Searle, R.F. (1979) Ia antigen expression on the developing mouse embryo and placenta. J. reprod. Immunol. 1, 3-10.

Jilek, F. \& Veselský, L. (1972) The occurrence of lymphocyte antigens on boar spermatozoa. J. Reprod. Fert. 31, 295-298.

Johnson, P.M. (1985) Cells and antigens at the maternofetal interface. Immunol. Today 6, 143-144.

Kagota, K., Abe, N. \& Tokoro, K. (1982) Clinicohematological studies on subclinical cases of neonatal hemolytic disease in pigs. Jpn J. ves. Res. 30, 79-93.

Kirby, D.R.S., Billington, W.D., Bradbury, S. \& Goldstein, D.J. (1964) Antigen barrier of the mouse placenta. Nature, Lond. 204, 548-549.

Koch, E. \& Ellendorf, F. (1985a) Prospects and limitations of the rosette inhibition test to detect activity of early pregnancy factor in the pig. J. Reprod. Fert. 74, 29-38.

Koch, E. \& Ellendorff, F. (1985b) Detection of activity similar to that of early pregnancy factor after mating sows with a vasectomized boar. J. Reprod. Fert. 74, 39-46.

Koch, E., Morton, H. \& Ellendorff, F. (1983) Early pregnancy factor: biology and practical application. $\mathrm{Br}$. vet. J. 139, 52-58.

Koch, E., Morton, H., Morton, D. \& Ellendorf, F. (1982) Früher Trächtigkeitsfaktor (EPF) beim Schwein. In Physiologie und Pathologie der Fortpflanzung, Verhandlungsbericht 7 . Veterinär-Humanmedizinische Tagung, pp. 168-170. Eds K. Semm, H. Tillmann, W. Gehring \& L. Mettler. Wissenschaftlicher Dienst Alete, Munich.

Krco, C.J. \& Goldberg, E.H. (1976) H-Y (male) antigen: detection on eight-cell mouse embryos. Science, N.Y. 193, $1134-1135$.

Krco, C.J. \& Goldberg, E.H. (1977) Major histocompatibility antigens on preimplantation mouse embryos. Transplant. Proc. 9, 1367-1370.

Linklater, K.A. (1975) The experimental reproducion of thrombocytopenic purpura in piglets. Res. vet. Sci. $18,127-133$. 
Loveland, B.E. \& McKenzie, I.F.C. (1982) Which T cells cause graft rejection? Transplantation 33, 217-221.

Lunney, J.K. \& Sachs, D.H. (1978) Transplantation in miniature swine. IV. Chemical characterization of MSLA and la-like antigens. $J$. Immunol. 120, 607-612.

Lunney, J.K. \& Sachs, D.H. (1979) Transplantation in miniature swine. V. Characterization of la antigens. J. Immunol. 122, 623-627.

Marrable, A.W. (1968) The ischaemic extremities of the allantochorion of the pig and their relation to the endometrium. Res, vet. Sci. 9, 578-582.

Matzinger, P. \& Zamoyska, R. (1982) A beginner's guide to major histocompatibility complex function. Nature, Lond. 297, 628.

McLaren, A. (1975) Antigenic disparity: does it affect placental size, implantation or population genetics? In Immunobiology of the Trophoblast, pp. 255-273. Eds R. G. Edwards, C. W. S. Howe \& M. H. Johnson. Cambridge University Press.

McRae, A. (1984) The blood-uterine lumen barrier and its possible significance in early embryo development. In Oxford Reviews of Reproductive Biology, Vol. 6, pp. 129-173. Ed. J. R. Clarke. Clarendon Press, Oxford.

Meuli, L.E., Kleiman, D. \& Bush, M. (1984) Evidence of early pregnancy factor in the giant panda in conjunction with urinary steroids. Proc. $10 \mathrm{th} \mathrm{Im}$. Congr. Anim. Reprod. \& A.I. Urbana-Champaign, Vol. 2, p. 91, Abstr.

Meziou, W., Chardon, P., Fléchon, J.E., Kalil, J. \& Vaiman, M. (1983) Expression of $\boldsymbol{\beta}_{2}$-microglobulin on preimplantation pig embryos. $J$. reprod. Immunol. $5,73-80$.

Miyasaka, M. \& McCullagh, P. (1981) Immunological responsiveness of matemal and foetal lymphocytes during normal pregnancy in the ewe. $J$. reprod. Immunol. 3, 15-27.

Moretta, L., Ferrarini, M., Mingari, M.C., Moretta, A. \& Webb, S.R. (1976) Subpopulations of human T cells identified by receptors for immunoglobulins and mitogen responsiveness. $J$. Immunol. 117, 2171-2174.

Morton, H. (1984) Early pregnancy factor (EPF): a link between fertilization and immunomodulation. Aust. J. biol. Sci. 37, 393-407.

Morton, H., Hegh, V. \& Clunie, G.J.A. (1974) Immunosuppression detected in pregnant mice by rosette inhibition test. Nature, Lond. 249, 459-460.

Morton, H., Hegh, V. \& Clunie, G.J.A. (1976) Studies of the rosette inhibition test in pregnant mice: evidence of immunosuppression? Proc. R. Soc. Lond. B 193, 413-419.

Morton, H., Rolfe, B., Clunie, G.J.A., Anderson, M.J. \& Morrison, J. (1977) An early pregnancy factor detected in human serum by the rosette inhibition test. Lancet i, 394-397.

Morton, H., Nancarrow, C.D., Scaramuzzi, R.J., Evison, B.M. \& Clunie, G.J.A. (1979) Detection of early pregnancy in sheep by the rosette inhibition test. $J$. Reprod. Fert. 56, 75-80.

Morton, H., Rolfe, B. \& Cavanagh, A. (1982a) Early pregnancy factor: biology and clinical significance. In Pregnancy Proteins, pp. 391-405. Eds J. G. Grudzinskas, B. Teisner \& M. Seppãlä. Academic Press, Sydney.
Morton, H., Tinneberg, H.R., Rolfe, B., Wolf, M. \& Mettler, L. (1982b) Rosette inhibition test: a multicentre investigation of early pregnancy factor in humans. $J$. reprod. Immunol. 4, 25I-261.

Morton, H., Morton, D.J. \& Ellendorf, F. (1983) Appearance and characteristics of early pregnancy factor in the pig. J. Reprod. Fert. 68, 437-446.

Muggleton-Harris, A.L. \& Johnson, M.H. (1976) The nature and distribution of serologically detectable alloantigens on the preimplantation mouse embryo. J. Embryol. exp. Morphol. 35, 59-72.

Mukherjee, A.B., Laki, K. \& Agrawal, A.K. (1980) Possible mechanism of success of an allo-transplantation in nature: mammalian pregnancy. Med. Hypotheses 6, 1043-1055.

Munro, A., Bewick, M., Manuel, L., Cameron, J.S., Ellis, F.G., Boulton-Jones, M. \& Ogg, C.S. (1971) Clinical evaluation of a rosette inhibition test in renal allotransplantation. Br. med. J. 3, 27!-275.

Murray, F.A., Segerson, E.C. \& Brown, F.T. (1978) Suppression of lymphocytes in vitro by porcine uterine secretory protein. Biol. Reprod. 19, 15-25.

Murray, F.A., Zurcher, V. \& Grifo, A.P. (1979) Suppression of lymphocyte reactivity in vitro by porcine allantoic and amniotic fuids. Theriogenology 11, 217-225.

Murray, F.A., Grifo, A.P. \& Parker, C.F. (1983) Increased litter size in gilts by intrauterine infusion of seminal and sperm antigens before breeding. J. Anim. Sci. 56, 895-900.

Nancarrow, C.D., Wallace, A.L.C. \& Grewal, A.S. (198I) The early pregnancy factor of sheep and cattle. $J$. Reprod. Fert.. Suppl. 30, 191-199.

Newman, M.J. \& Hines, H.C. (1980) Stimulation of maternal antilymphocyte antibodies by first gestation bovine fetuses. J. Reprod. Fert. 60, 237-241.

Noonan, F.P., Halliday, W.J., Morton, H. \& Clunie, G.J.A. (1979) Early pregnancy factor is immunosuppressive. Nature, Lond. 278, 649-65!.

Osborne, B.A., Lunney, J.K., Pennington, L., Sachs, D.H. \& Rudikoff, S. (1983) Two-dimensional gel analysis of swine histocompatibility antigens. $J$. Immunol. 131, 2939-2944.

Paisley, L.G., Davis, W.C., Anderson, P.B. \& Mickelsen, W.D. (1982) Detection of early pregnancy factor in swine: a need for dialogue. Theriogenology 18, 393-401.

Palm, J. (1974) Maternal-fetal histoincompatibility in rats: an escape from adversity. Cancer Res. 34, 2061-2065.

Pennington, L.R., Lunney, J.K. \& Sachs, D.H. (1981) Transplantation in miniature swine. VIII. Recombination within the major histocompatibility complex of miniature swine. Transplantation 31, 66-71.

Philip, P.J.M., Ayraud, N. \& Masseyeff, R. (1982) Transfer, tissue localization and proliferation of fetal cells in pregnant mice. Immunology Letr. 4, 175-178.

Purtilo, D.T., Hallgren, H.M. \& Yunis, E.J. (1972) Depressed maternal lymphocyte response to phytohaemagglutinin in human pregnancy. Lancet i, 769-771.

Reinherz, E.L., Moretta, L., Roper, M., Breard, J.M., Mingari, M.C., Cooper, M.D \& Schlossman, S.F. (1980) Human T lymphocyte subpopulations defined 
by $F_{c}$ receptors and monoclonal antibodies. $J$. exp. Med. 151, 969-974.

Rejnek, J. \& Prokesovà, L. (1973) Immunoglobulins and antibodics in pigs. In Contemporary Topics in Molecular Immunology, Vol. 2, pp. 117-153. Eds R. A. Reisfeld \& W. J. Mandy. Plenum Press, New York.

Roberts, G.P. (1977) Inhibition of lymphocyte stimulation by bovine uterine proteins. J. Reprod. Fert. 50, 337-339.

Rolfe, B.E., Morton, H., Cavanagh, A.C. \& Gardiner, R.A (1983a) Detection of an early pregnancy factorlike substance in sera of patients with testicular germ cell tumors. Am. J. reprod. Immunol. 3, 97-100.

Rolfe, B.E., Morton, H. \& Clarke, F.M. (1983b) Early pregnancy factor is an immunosuppressive contaminant of commercial preparations of human chorionic gonadotrophin. Clin. exp. Immunol. 51, 45-52.

Rudek, Z. \& Kwiatkowska, L. (1983) The possibility of detecting fetal lymphocytes in the maternal blood of the domestic pig, Sus scrofa. Cytogenet. Cell Genet. $36,580-583$.

Sachs, D.H. (1983) Overview of the MHC in mammalian systems. Transplans. Proc. 15, 40-44.

Samuel, C.A. (1971) The development of pig trophoblast in ectopic sites. J. Reprod. Fert. 27, 494-495.

Sargent, I.L. \& Redman, C.W.G. (1985) Maternal cellmediated immunity to the fetus in human pregnancy. J. reprod. Immunol. 7, 95-104.

Sawicki, J.A., Magnuson, T. \& Epstein, C.J. (1981) Evidence for expression of the paternal genome in the two cell mousc embryo. Nature. Lond. 294, $450-451$.

Schmid, D.O., Cwik, S., Krüusslich, H., Meyer, J. \& Graf zu Dohna, R. (1978) Über lymphozytotoxische Antikörper bei weiblichen Zuchtschweinen. Zentbl. Vet. Med. B 25, 517-523.

Searle, R.F., Sellens, M.H., Elson, J., Jenkinson, E.J. \& Billington, W.D. (1976) Detection of alloantigens during preimplantation development and early trophoblast differentiation in the mouse by immunoperoxidase labeling. J. exp. Med. 143, 348-359.

Searle, R.F., Billington, W.D., Whyte, A. \& Loke, Y.N. (1981) Detection of human and murine trophoblastspecific antigens and an assessment of their species specificity. Placenta 2, 93-104.

Segerson, E.C. (1981) Immunosuppressive effect of ovine uterine secretory protein upon lymphocytes in vitro. Biol. Reprod. 25, 77-84.

Sellens, M.H., Jenkinson, E.J. \& Billington, W.D. (1978) Major histocompatibility complex and non-major histocompatibility complex antigens on mouse ectoplacental cone and placental trophoblastic cells. Transplantation 25, 173-179.

Simpson, E. (1984) The cellular basis of the immune response. In Immunological Aspects of Reproduction in Mammals, pp. I-ll. Ed. D. B. Crighton. Butterworth, London.

Skjervold, H., Almlid, T., Onstad, O. \& Fossum, K. (1979) Evidence of immunological influence on the number of live embryos in pigs. Z. tierzücht. Züchtgsbiol. 96, 235-236.

Smart, Y.C., Roberts, T.K., Fraser, I.S., Cripps, A.W. \& Clancy, R.L. (1982) Validation of the rosette inhibi- tion test for the detection of early pregnancy in women. Fert. Steril. 37, 779-785.

Stahn, R., Fabricius, H.A. \& Hartleitner, W. (1978) Suppression of human T-cell colony formation during pregnancy. Nature, Lond. 276, 831-832.

Suciu-Foca, N., Reed, E., Rohowsky, C., Kung, P. \& King, D.W. (1983) Anti-idiotypic antibodies to antiHLA receptors induced by pregnancy. Proc. natn. Acad. Sci. U.S.A. 80, 830-834.

Sunderland, C.A., Redman, C.W.G. \& Stirrat, G.M. (1981) HLA A, B, C antigens are expressed on nonvillous trophoblast of the early human placenta. J. Immunol. 127, 2614-2615.

Thomson, A.W., Milton, J.I., Campbell, D.M. \& Horne, C.H.W. (1980) Rosette inhibition levels during early human gestation. J. reprod. Immunol. 2, 263-268.

Tofoski, J.G. \& Gill, T.J. (1977) The production of migration inhibitory factor and reproductive capacity in allogeneic pregnancies. Am. J. Pathol. 88, 333-344.

Vaiman, M. \& Renard, C. (1980) Deficit of piglets homozygous for the SLA histocompatibility complex in families. Anim. Blood Grps Biochem. Genetics 11, Suppl. 1, 57, Abstr.

Vaiman, M., Renard, C., LaFage, P., Ameteau, J. \& Nizza, P. (1970) Evidence for a histocompatibility system in swine (SL-A). Transplantation 10, 155-164.

Vaiman, M., Chardon, P. \& Renard, C. (1979) Genetic organisation of the pig SLA complex. Studies on nine recombinants and biochemical and lysostrip analysis. Immunogenetics 9, 353-361.

Veselský, L., Staněk, R. \& Hradecký, J. (198I) Effect of antibodies to boar spermatozoa on fertility in sows and rabbits. Archs Androl. 7, 337-342.

Viza, D., Sugar, J.R. \& Binns, R.M. (1970) Lymphocyte stimulation in pigs: evidence for the existence of a single major histocompatibility locus, PL-A. Nature, Lond. 227, 949-950.

Voisin, G.A. \& Chaouat, G. (1974) Demonstration, nature and properties of maternal antibodies fixed on placenta and directed against paternal antigens. $J$. Reprod. Fert., Suppl. 21, 89-103.

Wegmann, T.G., Waters, C.A., Drell, D.W. \& Carlson, G.A. (1979) Pregnant mice are not primed but can be primed to fetal alloantigens. Proc. natn. Acad. Sci. U.S.A. 76, 2410-2414.

Whyte, A. \& Heap, R.B. (1983) Early pregnancy factor. Nature, Lond. 304, 121-122.

Whyte, A., Bacon, M. \& Ellis, S. (1984) A monoclonal antibody to an antigen present on the microvillous membrane of the trophectoderm of the preimplantation blastocyst of the pig. J. Reprod. Fert. 71, 599-605.

Wilson, S., McCarthy, R. \& Clarke, F. (1983) In search of early pregnancy factor: isolation of active polypeptides from pregnant ewes' sera. J. reprod. Imminol. 5, 275-286.

Wilson, S., McCarthy, R. \& Clarke, F. (1984) In search of early pregnancy factor: characterisation of active polypeptides isolated from pregnant ewes' sera. $J$. reprod. Immunol. 6, 253-260.

Wybran, J., Levin, A.S., Spitler, L.E. \& Fudenberg, H.H. (1973) Rosette-forming cells, immunologic deficiency diseases and transfer factor. N. Engl. J. Med. 288, $710-713$. 